\title{
Yerel Yönetimlerin Finansmanında Yerel Yönetim Bankacılığı Uygulaması, İller Bankası Örneği ve Türkiye İçin Öneriler
}

\author{
Mustafa GÜMÜŞ, Capital Markets Board of Turkey; e-mail: mustafa.gumus@spk.gov.tr \\ Ahmet Burçin YERELI, Department of Public Finance, Faculty of Economics and Administrative Sciences, \\ Hacettepe University, Turkey; e-mail: aby@hacettepe.edu.tr
}

\section{Municipal Bond Banks for Local Government Finance, Ilbank Case and a Proposal for Turkey}

\begin{abstract}
Although, debt requirements of local governments in Turkey were satisfied basically through two main venues, İller Bankası and commercial banks, recent years recorded an increase in usage towards commercial banks. Municipal Bond Banking Model, which has been used for raising funds from capital markets for local governments has been a videly used method in various countries under different procedures, is not seen as an active model in Turkey. In our study, aside from providing information about Municipal Bond Banking Model, we are putting emphasis on the availability of this model as an alternative source of local governments funding focusing on Tukey and İller Bankas1 operations.
\end{abstract}

Keywords $\quad$ : Municipal Bonds, Municipal Bond Banks, Ilbank, Local Government Finance.

JEL Classification Codes : $\mathrm{H} 74$.

\section{Öz}

Türkiye'de yerel yönetimlerin borçlanma ihtiyaçları temelde İller Bankası veya ticari bankalar aracılığıyla gerçekleştirilirken, son yıllarda ibre ikincisi lehine hızla artmaktadır. Pek çok ülkede farklı adlar altında uygulanan ve yerel yönetimlere sermaye piyasalarından kaynak sağlamakta değerlendirilen yerel yönetim bankacılığı uygulama modeli ise işletilememektedir. Çalışmamızda yerel yönetim bankacılığı uygulamaları hakkında bilgilendirme yapılırken, özellikle Türkiye ve İller Bankası örneğinde bu modelin nasıl uygulanabileceğine ilişkin modeller önerilerek, yerel yönetimlerin finansmanında farklı bir kaynak oluşturulabileceği üzerinde durulmaktadır.

Anahtar Sözcükler $\quad$ : Yerel Yönetimlerin Finansman1, Yerel Yönetim Tahvilleri, Yerel Yönetim Bankacılığı, İlbank (İller Bankası A.Ş.). 
Gümüş, M. \& A.B. Yereli (2016), "Yerel Yönetimlerin Finansmanında Yerel Yönetim Bankacıllı̆ı

Uygulaması, İller Bankası Örneği ve Türkiye İçin Öneriler”, Sosyoekonomi, Vol. 24(28), 209-234.

\section{Giriş}

Son yıllarda özellikle az gelişmiş ve gelişmekte olan ülkelerde yaşanan nüfus artışı, artan kentleşme oranları ve yaşam standartlarındaki yükseliş yerel yönetimlerin hizmet götürmekle mükellef olduğu yerel halkın yatırım ve hizmet taleplerini arttırmıştır. Kentsel nüfus, sosyal ve nispeten konforlu ve teknolojik bir hayat talep etmekte olup, bunun karşılanması da ayrı bir maliyet unsuru olarak karşımızda durmaktadır. İdari sistemlerde gözlenen yerelleşme düzeyindeki artı̧̧ da yerel yönetimlerin yetki ve sorumluluklarını artırmıştır.

McKinsey Global Institute tarafından yapılan bir çalışmada (McKinsey Global Institute, 2013: 2-3) 2013-2030 yılları arasındaki dönemde dünya genelinde yapılması gereken altyapı yatırım tutarı, geçmiş dönemde altyapı yatırımlarına yapılan yatırımlar dikkate alındığında 62 trilyon ABD Doları (USD), toplam altyapı yatırım stoklarının gayrisafi milli hasılanın bir oranı şeklinde bir varsayımdan hareket edildiğinde 67 trilyon USD ve gayrisafi milli hasıla artışı ile nüfus artış hızı varsayımları çerçevesinde bir projeksiyon yapıldığında ise 57 trilyon USD olarak tespit edilmiştir. Bu da yaklaşık 3,5 trilyon USD yıllık yatırım yapılması demektir.

Ülkemiz açısından da durum farklı görünmemektedir. Ülkemizin 2023 yılına kadar yaklaşık 700 milyar USD tutarında bir alt yapı yatırımına ihtiyacı bulunmaktadır (Babacan, 2014: 5). Bu tutarın ne kadarlık kısmının merkezi hükümet, ne kadarlık kısmının yerel yönetimler tarafindan yerine getirileceği net olarak ortaya konulamasa da; yerel yönetimlere de önemli görevler düştüğü bir gerçektir.

$\mathrm{Bu}$ yatırımlar hem inşaat süresi hem elde edilecek gelir ve kullanma süresi itibarıyla uzun vadeli kaynak gerektirdiğinden, öz kaynakla finanse etmek yerine borçlanma ile finanse etmek finansal ve sosyoekonomik açıdan daha mantıklıdır. Borçlanma ile finansman durumunda karşımıza 3 seçenek çıkmaktadır. Bunlardan ilki yerel yönetimlerin merkezi yönetime borçlanmasıdır. İkinci yöntem bankacılık sisteminden borçlanma, son yöntem ise sermaye piyasalarından borçlanmadır.

İlk yöntem ülke ekonomisinin genel durumu, toplam kamu borç yükü, faiz oranları gibi faktörlere göre değişebilmekle birlikte, özellikle az gelişmiş ve gelişmekte olan ülkelerde eğitim, sağlık gibi temel hizmetlerin dahi yapılırken kaynak bulmakta zorlanıldığ düşünülürse, gerçekleştirilmesi zor bir yöntem olduğu kabul edilebilir. Merkezi yönetimden borçlanma olsa dahi hangi yerel yönetimlere, hangi projeler karşılı̆̆ında borç verileceği gibi cevabını bulmakta zorlanılacak sorular ile karşı karşıya kalınabilecektir. Ayrıca merkezi hükümetin, tüm ülke genelinden topladığı kaynakları belirli projelere aktarması da etik olarak tartışmaya açık bir konudur.

İkinci yöntem bankacılık sisteminden borçlanma yoluyla yatırımlarının finanse edilmesidir. $\mathrm{Bu}$ yöntem, sermaye piyasalarının tam olarak gelişmediği ya da bankacılık sisteminin ağırlıkta olduğu ülkelerde karşımıza çıkmaktadır. Bankacılık sistemi kredi 
maliyetleri yüksek olsa dahi kullanması herhangi bir uzmanlık ya da alt yapı gerektirmeyen ve yerel yönetimler açısından da kolay olarak ulaşılabilen kaynaklardır. Ancak bu kaynaklarda da, özellikle büyük yatırımlar açısından, karşımıza vade sorunu çıkmaktadır. Zira bankacılık sistemi mevduata dayalı olarak kredi verdiğinden, mevduatların kısa vadeli yapısı uzun vadeli finansman ihtiyacı olan bu tür yatırımların tamamını finanse etmekte zorlanacaktır.

Özellikle 2009 yılı ve sonrasında yaşanan uluslararası finansal kriz ve sonrası dönemde bankaların finansal sağlamlığı öncelikli bir konuma gelmiştir. BASEL III gibi düzenlemeler ve katı sermaye tabanı kuralları uygulamaları bu tür yatırımların bankalar tarafından finansmanında engeller oluşturmaktadır (Babacan, 2014: 5).

Üçüncü yöntem sermaye piyasalarından borçlanma yoluyla altyapı yatırımlarının finanse edilmesidir. Gerek nesiller arası adalet, gerek uzun vadeli gelir yaratmaları dolayısıyla bu tür yatırımların uzun vadeli kaynaklarla finanse edilmesi iyi bir seçenek olarak karşımıza çıkmaktadır. Bu tür finansman yöntemi özellikle Amerika Birleşik Devletleri (ABD) ve Kanada'da sık kullanılan ve genellikle de tahvil ihracı suretiyle yapılan borçlanma şeklidir.

Bankacılık sistemi ile sermaye piyasalarını birleştiren bir seçenek ise yerel yönetim bankacılığı uygulamasıdır. Çoğunlukla merkezi yönetime ya da yerel yönetimlere ait olan bu bankalar, düşük maliyetlerle sermaye piyasalarından borçlanmak ve sağladığı kaynakları uygun faiz oranları ve vadelerle yerel yönetimlere aktarmak suretiyle yerel yönetimlerin finansmanında önemli bir işlev üstlenmektedirler.

Çalışmamızda yerel yönetimlerin finansmanında uzun yıllardır önemli bir kaynak olan ve sermaye piyasaları ile bankacılık sistemini bu anlamda birleştiren yerel yönetim bankacılığı uygulaması hakkında uluslararası uygulamalar da dikkate alınarak bilgilendirme yapıldıktan sonra, İller Bankası AŞ.'nin (İlbank) mevcut durumu bu çerçevede değerlendirilerek, ülkemiz için öneriler geliştirilmeye çalışılacaktır.

\section{Genel Olarak Yerel Yönetim Bankacılı̆̆ı Uygulaması}

Bankacılık sisteminin yerel yönetimlere sunduğu önemli bir kaynak yerel yönetim bankacılığı veya eyalet veya devlet tahvil bankaları aracılığıyla oluşturulan kaynaklardır (municipal bond banks veya state bond banks). Vogt (1984: 38) yerel yönetim bankasını finansal özerkliğe sahip bir kamu kuruluşu olup, vergiden muaf menkul kıymetler ihraç eden ve karşılığında topladığı paralarla da yerel yönetim tahvillerine yatırım yapan banka olarak tanımlamıştır. 1956 yılında Kanada'da, 1970 ve devamı yıllarda ABD’nin farklı eyaletlerinde kurulan ve Avrupa Birliği üyesi ülkelerde de yaygın uygulamaları olan yerel yönetim bankaları, 3 nedenden dolayı yerel yönetimlerin daha düşük maliyetle yatırımlarını finanse etmelerini sağlayabilmektedir (Vogt, 1984: 38; Kidwell \& Rogowski, 1983: 109). Bunlar yerel yönetim bankalarının genellikle yerel yönetimlerden daha yüksek kredibiliteye sahip olması, yaptıkları ihraçların büyük tutarlı olmaları nedeniyle ölçek 
ekonomilerinden faydalanmaları ve son olarak da sahip oldukları tecrübe ve bilgi birikimi dikkate alınarak yerel yönetimlere göre daha geniş bir alıcı kitlesine ulaşabilmeleridir. Yüksek tutarlı ihraç nedeniyle maliyet düşüşü sağlanacak giderler finansal danışmanlık ücretleri, kredi derecelendirme notu alınması, reklam ve pazarlama giderleri, basım masrafları olarak belirtilebilir (Katzman, 1980: 153).

Yerel yönetimleri küçük ölçekli ve büyük ölçekli olarak ayırdığımızda konuya farklı açıdan bakılabilir. Küçük ölçekli yerel yönetimler için yukarıda saydığımız hususların hepsi geçerli iken, büyük ölçekli yerel yönetimlerin daha sık borçlanma aracı ihraç ettikleri, bu konuda bir bilgi birikimine ve yönetim kapasitesine sahip oldukları ve geçmiş tecrübelerine bağlı olarak bir dağıtım ağına sahip oldukları söylenebilir (Robbins \& Kim, 2003: 92-93).

Forbes ve Renshaw Vermont Yerel Yönetim Bankasının 1970 yılında yaptığı 46 milyon dolar tutarındaki ilk ihracını analiz etmişler ve ihraca katılan yerel yönetimlerin faiz ödemelerinden yaklaşık 3 milyon dolar tasarruf ettiklerini ortaya koymuşlardır (Aktaran: Cole \& Millar, 1982: 71).

Katzman ise (1980: 150, 154-155) 1976 yılı Ocak ayı itibarıyla yerel yönetimler tarafından gerçekleştirilen 8 ihracın Maine Yerel Yönetim Bankası ve Vermont Yerel Yönetim Bankası tarafındangerçekleştirilmiş olması varsayımı altında; faiz ve pazarlama maliyetlerindeki azalmayı ihraç maliyetinin sırasıyla \%4,4'ü ve \%3,8'i olarak hesaplamıştır. Söz konusu maliyet düşüşünün sırasıyla $\% 78$ ve $\% 71$ 'i faiz oranlarındaki olası düşmeden, yaklaşık \%17'si ise pazarlama maliyetlerindeki düşmeden kaynaklanmaktadır. Maliyet düşüşü hesaplanırken yerel yönetim bankasının olmadığı varsayımı altında yerel yönetimlerin benzer ihraç tutarı ve kredi derecelendirmesine sahip ihraçlarla eşit faiz ve pazarlama ve ihraç maliyetlerine katlanacağı varsayılmıştır.

ABD’de yapılan üç çalışma [Cole ve Millar (1982), Katzman (1980), Kidwell ve Rogowski (1983)] yerel yönetim bankalarının yerel yönetimlerin borçlanmasında daha düşük maliyet sağladığını ortaya koymuştur. Bu çalışmalar, yerel yönetim bankalarının hem kredi derecelendirme hem de ölçek ekonomisinden kaynaklanan nedenlerle daha düşük maliyetle borçlanmaya imkân verdiğini, kredi derecelendirme notu eşit dahi olsa ölçek ekonomisi nedeniyle yerel yönetim bankalarının düşük maliyetle borçlanma sağladıklarını ortaya koymuştur. Diğer taraftan yerel yönetimlerin yerel yönetim bankalarından daha yüksek kredi derecelendirmesine sahip olmaları durumunda düşük maliyetle borçlanma gerçekleştiremedikleri görülmüştür (Aktaran: Rhee \& Stone, 2003: 2).

Yerel yönetim bankaları kamu sermayeli bankalar olmaları nedeniyle alıkoyma mekanizması (interceptmechanism) diyebileceğimiz bir yöntemi de kullanmaktadırlar. Bu yöntemle yerel yönetim bankaları yerel yönetimin anapara ve faiz ödemelerinde temerrüde düştüğü durumlarda, söz konusu ödemeler merkezi yönetim tarafından yapılan yardımlardan ve diğer yönetimler arası transferlerden dağıtım sırasında öncelikli olarak karşılanmaktadır (Robbins \& Kim, 2003: 95). 
Yerel yönetim bankalarının yerel yönetimlerin finansmanı sağlamasına ilişkin süreç iki şekilde gerçekleşmektedir (Rhee \& Stone, 2003: 7-12) Bunlara ilişkin tablolar aşağıda yer almakta olup, ilki yerel yönetim bankasının piyasadan doğrudan kendi adına borçlanması (gelire dayalı tahviller ihraç etmek suretiyle) ve bu kaynağı yerel yönetimler tarafından çıkarılan genel yükümlülük tahvillerini satın alarak veya kredi vererek yerel yönetimlere aktarması şeklinde olmaktadır. İkinci yöntemde ise yerel yönetim bankası yerel yönetimlerin borçlanma ihtiyaçlarını tespit eder ve bu ihtiyaç ve talepleri dikkatealarak tek bir büyük havuz oluşturarak borçlanma aracı ihraç eder. Bu şekilde borçlanmanın büyüklüğünden ve borçluların sayısındaki artışa bağlı olarak geri ödeyememe riskinin azalmasından maliyet avantajı sağlanmış olmaktadır (Cole \& Millar, 1982: 71). Bu iki süreç öncesinde yerel yönetimlerin kendi mevzuatları uyarınca borçlanmaya karar vermeye yetkili kurullarda karar almaları veya varsa ilgili mercilerden izin almaları gerektiği de açıktır. İkinci yöntemde yerel yönetim bankası sürecin başında yerel yönetimler tarafindan ihraç edilen borçlanma araçları satın alıp, bunlardan bir havuz oluşturup, bunları teminat (dayanak) göstermek suretiyle de borçlanma aracı ihracı yoluna gidebilmektedir (Robbins \& Kim, 2003: 95).

Şekil: 1

\section{Yerel Yönetim Bankasının Gelire Endeksli Tahvil İhraç Etmesi}

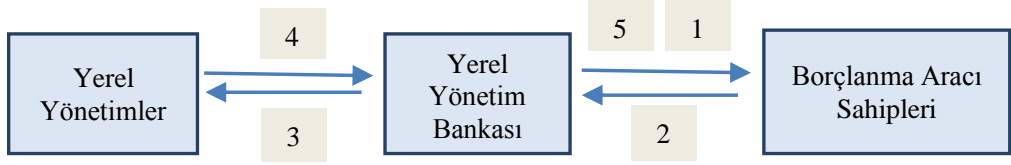

Yukarıdaki şekil çerçevesinde gerçekleştirilen ihraç aşağıdaki şekilde açıklanabilir:

1 Yerel yönetim bankası borçlanma aracı ihraç eder.

2-3 Borçlanmadan elde edilen gelirler ile yerel yönetimler tarafindan ihraç edilen borçlanma araçları satın alınır.

4 Yerel yönetimler borçlanma araçları dolayısıyla ödemeleri gereken faiz ve anapara tutarlarını yerel yönetim bankasına öderler.

5 Yerel yönetim bankası kendi ihraç ettiği borçlanma aracı dolayısıyla ödemek zorunda olduğu faiz ve anapara tutarlarını yerel yönetimlerden tahsil ettiği tutarları kullanarak öder.

Şekil: 2

Yerel Yönetim Bankasının Yerel Yönetimlerin Taleplerinden Havuz Oluşturarak Borçlanma Aracı İhraç Etmesi

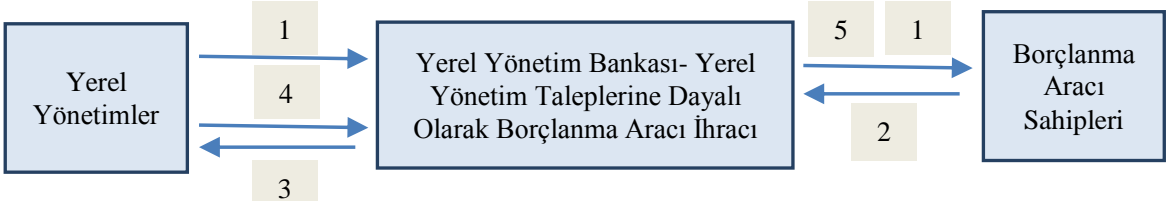


Gümüş, M. \& A.B. Yereli (2016), "Yerel Yönetimlerin Finansmanında Yerel Yönetim Bankacıllı̆̆1

Uygulaması, İller Bankası Örneği ve Türkiye İçin Öneriler”, Sosyoekonomi, Vol. 24(28), 209-234.

\section{açıklanabilir:}

Yukarıdaki grafik çerçevesinde gerçekleştirilen ihraç aşağıdaki şekilde

1 Yerel yönetimler borçlanma ihtiyaçlarını yerel yönetim bankasına iletirler. Yerel yönetim bankası yerel yönetimlerden gelen talepleri kendi belirlediği kriterlere göre değerlendirir, taleplerden bir havuz oluşturarak borçlanma aracı ihracı yapar. Gerek görmesi durumunda talepleri reddeder. Borçlanma aracı ihracı için asgari belirli bir tutarda talep toplanması veya düzenli aralıklarla borçlanma aracı ihracı gerçekleştirmesi yöntemlerinden birisi tercih edilir.

2-3 Borçlanmadan elde edilen gelirler ile yerel yönetimler tarafından ihraç edilen borçlanma araçları satın alınır veya doğrudan yerel yönetimlere kredi verilir. Borçlanmada talep toplamının yaklaşık $\% 10$ üzerinde bir ihraç gerçekleştirilerek bir rezerv fonu oluşturulur.

4 Yerel yönetimler borçlanma araçları dolayısıyla ödemeleri gereken faiz ve anapara tutarlarını yerel yönetim bankasına öderler.

5 Yerel yönetim bankası kendi ihraç ettiği borçlanma aracı dolayısıyla ödemek zorunda olduğu faiz ve anapara tutarlarını yerel yönetimlerden tahsil ettiği tutarları kullanarak öder.

Yerel yönetim taleplerinden havuz oluşturulmasına ilişkin süreç, yerel yönetim bankasının yerel yönetimlerin borçlanma taleplerini almasının yerine onlar tarafından ihraç edilen borçlanma araçlarını satın alması ve teminat göstermek suretiyle kendi borçlanma araçlarını ihraç etmesi şeklinde de uygulanabilmektedir (Robbins \& Kim, 2003: 95).

Yerel yönetim bankasının doğrudan borçlanma aracı ihraç etmesi veya yerel yönetimlerden talep toplayıp bir havuz oluşturarak borçlanma aracı ihraç etmesi arasında ABD örneğindeki en önemli fark yaklaşık bir yıllık anapara ve faiz tutarı ödemelerine karşılık gelecek düzeyde bir rezerv fonun oluşturulması olarak görülmektedir (Rhee \& Stone, 2003: 10). Oluşturulan bu rezerv fon, faiz ve anapara geri ödemelerinin garantisi olarak görülmekte, hem borçlanma aracının kredi derecelendirme notunu artırmakta hem de borçlanma maliyetinde düşmeye neden olmaktadır. (Katzman, 1980: 150).

\section{Dünyada Yerel Yönetim Bankacılığı Uygulamları}

$\mathrm{Bu}$ başlık altında dünya uygulamaları ABD, Finlandiya ve Japonya örnekleri hakkında bilgiler verilmek suretiyle incelenecektir. 


\subsection{Amerika Birleşik Devletleri}

Yerel yönetim bankaları eyaletlerin daha küçük birimlerinin düşük maliyetle borçlanmalarını sağlamaya yönelik olarak oluşturulan ve genellikle kamu mülkiyetinde bulunan bankalardır. Hizmet sundukları yerel yönetim birimlerinden daha iyi kredi derecelendirmesine ve hizmet ağı ve tecrübesine sahip oldukları için genellikle daha düşük oranda borçlanma imkânlarına sahiptirler.

Eyaletlerin tamamında bulunmayan yerel yönetim bankaları, Maine, Indiana, Idaho, New Hampshire, New York, Alaska, North Dakota, Illinois, Michigan, Oregon, Newyork ve Vermont eyaletlerinde bulunmaktadır (Robbins \& Kim, 2003: 94). Yaklaşık olarak benzer işlevleri gördüklerinden ve örnek olması açısından Vermont Yerel Yönetim Bankasıhakkında bilgiler verilerek ABD uygulaması anlatılmaya çalışılacaktır.

\subsubsection{Vermont Yerel Yönetim Bankası ${ }^{1}$}

1969 yılında kurulan Vermont Yerel Yönetim Bankası (VYYB) kamu sermayeli olup, yönetim kurulu Eyalet Valisi tarafindan atanmaktadır. 2013 yılı sonu itibarıyla Banka'nın yerel yönetimlere kullandırdığı kredi tutarı 2 trilyon USD'yi bulmuştur. Vermont Eyaleti tarafindan yönetim birimi olarak kabul edilen her düzeyde kurum Banka'dan kredi kullanabilmektedir.

VYYB Standard and Poors ve Moodys tarafından verilmiş olan AA+ ve Aaa kredi notlarına sahiptir. Banka borçlanma aracı ihraç etmek istediğinde tüm talepleri tek bir ihraç havuzunda birleştirmekte, gerekli görülmesi durumunda tahvil sigortası ihraç sürecine dâhil edilmekte, takiben kredi derecelendirme kuruluşlarından görüş alınmakta, sirküler (officialstatement) hazırlanarak yatırım kuruluşlarına iletilmekte, borçlanma araçları öncelikle Vermont'ta yaşayan bireysel yatırımcılara takiben de kurumsal yatırımcılara pazarlanmaktadır. Faiz oranları ise ulusal faiz oranları, yakın dönemli benzer finansman maliyetleri, yatırımcı talepleri dikkate alınarak yüklenici firma (underwriter) ile pazarlık usulüyle belirlenmektedir.

Tahviller genellikle yılda bir defa Haziran ya da Temmuz aylarında ihraç edilmekte ve ihracı takip eden gün yerel yönetimlere aktarılabilmektedir. Tahviller sabit faizli olarak ihraç edilmekte olup, faiz dalgalanmalarından yerel yönetimler olumsuz etkilenmemektedirler. Anapara ödemeleri her yıl Kasım ayının 15'inde, ara dönem kupon ödemeleri ise yılda iki defa 15 Mayıs ve 15 Kasım aylarında yapılmaktadır. Erken itfa 
uygulaması genellikle kabul edilmemektedir, zira ihraç bir havuz oluşturularak gerçekleştirildiği için bir yerel yönetimin borcunu ayırmak mümkün olmamaktadır.

Banka tarafından iki çeşit tahvil ihracı yapılmaktadır. Bunlar kamulaştırma, gayrimenkul yapımı, su ve kanalizasyon sistemleri, mevcut borcun finansmanı veya mevcut altyapı yatırımların finansmanı amacıyla yapılan "genel yükümlülük tahvilleri” veya elektrik üretim tesisleri, katı atık depolama sistemleri, su dağıtım ve arıtma sistemleri, elektrik, gaz ve ısınma yatırımları gibi yatırımların finansmanında kullanılan "gelire endeksli tahviller" şeklinde olmaktadır.

Tahvil yatırımcıları büyük ölçüde bireysel yatırımcılar olurken, bankalar, fonlar ve sigorta şirketleri de talepte bulunabilmektedirler. Tahviller hem eyalet düzeyinde hem de federal düzeyde gelir vergisinden muaftırlar.

2013 yılında 30 yıl vadeli yıllık kupon ödemeli 54.895 milyon USD tutarındaki ihraç yıllık \%3,92 maliyet üzerinden gerçekleştirilmiştir. Söz konusu maliyetin içerisine yerel yönetim bankasının komisyonları ve ücretleri de dâhildir. Dolayısıyla yerel yönetimler açısından borçlanma maliyeti olarak ifade edilebilir. Aynı dönemde federal hükümet tarafından yapılan borçlanma araçlarında oluşan borçlanma maliyeti ise \%3,22 olarak gerçekleşmiştir ${ }^{2}$. Benzer şekilde Banka 2012 yılında 30 yıl vadeli yılda bir kupon ödemeli 36.125 milyon USD tutarında ihraç gerçekleştirmiş, söz konusu ihracın net faiz maliyeti ise \%3,34 olarak gerçekleşmiştir. Aynı dönemde federal hükümet tarafından yapılan borçlanma araçlarında oluşan borçlanma maliyeti ise \%2,25 olarak gerçekleşmiştir ${ }^{3}$. Görüldüğü üzere Vermont Yerel Yönetim Bankası Amerikan Hazinesi'nin sadece 50-100 baz puan aralığında daha yüksek bir maliyetle ancak kendi ücret ve komisyonları içinde olacak şekilde borçlanma gerçekleştirebilmiştir.

Banka her yıl en az bir kere tahvil ihracı gerçekleştirmekte olup, kuruluşundan bu yana 75 seri tahvil ihracı gerçekleştirmiştir. Söz konusu tahviller yeni bir borçlanma veya mevcut borçların refinansmanı amacıyla yapılan tahvil ihraçları şeklinde olabilmektedir. VYYB 2013 yılında gerçekleştirdiği tahvil ihracı ile 25 adet yerel yönetim biriminin borçlanma talebini yerine getirmiştir (Vermont, 2014: 6).

Tahvillerin vadesi 5 yıl ila 30 yıl arasında değişebilmekte olup, tahvil ihraç süreci aşağıdaki tabloda gösterilmektedir:

$<$ http://www.treasury.gov/resource-center/data-chart-center/interestrates/Pages/TextView.aspx?data $=$ longtermrateYear\&year $=2013>$, 25.06.2014.

3

$<$ http://www.treasury.gov/resource-center/data-chart-center/interest-

rates/Pages/TextView.aspx?data $=$ longtermrateYear\&year $=2013>$, 25.06.2014. 


\section{Tablo: 1}

\section{VYYB Tahvil İhraç Süreci}

Yerel Yönetimler VYYB'ye satmak üzere borçlanma aracı (tahvil) ihraç ederler<smiles>CC1CCCC1</smiles>

VYYB söz konusu borçlanma araçlarını teminat göstererek bir varlık havuzu oluşturur ve ulusal sermaye piyasalarında kendi adına borçlanma aracı ihraç eder

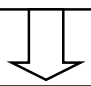

VYYB kendi tahvil ihracından elde ettiği gelirleri satın aldığı yerel yönetim tahvilleri ödemelerinde

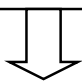

Yerel yönetimler elde ettikleri bu fonları yatırım harcaması bașta olmak üzere harcamalarında kullanır

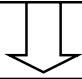

Yerel yönetimler VYYB'ye olan anapara ve faiz ödemelerini gerçekleștirir

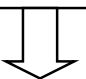

VYYB yerel yönetimlerden yaptığı tahsilatları kendi borçlanma araçlarının anapara ve faiz ödemelerinde kullanır

\subsubsection{Vermont Yerel Yönetim Bankası Mali Yapısı}

Aşağıdaki tabloda Banka’nın faaliyet alanını göstermesi bakımından 2010-2013 yılları arasındaki gelir-gider yapısı ve bazı bilanço büyüklüklerine ilişkin rakamlar verilmektedir. Rakamlardan da görüleceği üzere Banka çok düşük sermaye ile çalışmakta, finansmanını borçlanma aracı ihraç etmek suretiyle sağlamakta ve bunun da tamamına yakınını yerel yönetimlere kullandırmaktadır. Bankanın gelirlerinin \%85-90'ını faiz gelirleri, benzer şekilde giderlerinin de $\% 90$ ve üzerini faiz giderleri oluşturmaktadır

Tablo: 2

VYYB'nin 2010-2013 Yılları Arasındaki Gelir-Gider Yapısı, Bilanço Büyüklükleri

\begin{tabular}{|l|c|c|c|c|}
\hline & $\mathbf{2 0 1 0}$ & $\mathbf{2 0 1 1}$ & $\mathbf{2 0 1 2}$ & $\mathbf{2 0 1 3}$ \\
\hline Aktif Toplamı & 539.003 .312 & 583.286 .357 & 595.510 .130 & 602.758 .262 \\
\hline Krediler & 480.231 .933 & 519.525 .547 & 531.232 .756 & 540.853 .109 \\
\hline Borçlanma Araçları & 516.646 .775 & 556.189 .651 & 566.170 .957 & 593.802 .290 \\
\hline Sermaye & 20.142 .204 & 24.324 .402 & 26.399 .050 & 22.595 .541 \\
\hline Faiz Gelirleri & 22.226 .593 & 22.063 .339 & 21.597 .588 & 24.074 .146 \\
\hline Faiz Giderleri & 20.438 .298 & 22.379 .904 & 21.807 .967 & 21.781 .026 \\
\hline Faaliyet Giderleri & 368.138 & 353.672 & 487.093 & 1.277 .359 \\
\hline
\end{tabular}

Kaynak: VYYB, 2011-2013 yllarl arast finansal tablolarl, <http://www.vmbb.org/about/annual-reports-audits/>, 25.05.2014. 


\subsection{Finlandiya}

Kuzey Avrupa ülkelerinden üniter yapıya sahip olan Danimarka, İsveç ve Finlandiya yüksek düzeyde yerelleşme düzeyine sahip olup, yerel yönetimler vatandaşlarına geniş bir yelpazede hizmet sunmaktadırlar. Merkezi yönetim ile yerel yönetimler arsındaki hizmet paylaşımı, gelirlerin ve harcamaların paylaşılmasında da paralel bir durum ortaya çıkarmıştır. Yerel yönetimlerin borçlarının gayrisafi milli hasılaya oranı \%8'ler seviyesine kadar çıkmış ve son yıllarda sürekli artmıştır (Tablo 3). Diğer taraftan 2013 yılı sonu itibarıyla faiz giderlerinin yerel yönetimlerin toplam giderleri içindeki payı da \%4'ler seviyesindedir (MUNIFINN, 2015: 7).

Borçlanmaya ilişkin verilere bakıldığında 2010 yılında borçlanmanın toplam gelirler içindeki payı \%4 iken, $2012^{4}$ ve 2013 yıllarında bu oran \%7 olarak gerçekleşmiştir (MUNIFIN, 2015: 7) . Finlandiya'da yerel yönetimlerin yıllar itibarıly borç tutarları, borçlanma türleri ile bunun gayrisafi milli hasılaya oranları aşağıdaki tabloda verilmektedir. Diğer Kuzey Avrupa ülkelerinde olduğu üzere ${ }^{5}$ Finlandiya'da yerel yönetimlerin borçlanması son yıllarda önemli miktarda artış göstermiştir. Yerel yönetimlerin borçlanmaları uzun vadeli olup, doğrudan sermaye piyasalarından borçlanmaları düşük düzeydedir. Bununla birlikte uzun dönemli borçlanmalarında yerel yönetim bankacılı̆̆ kaynaklarına başvurmaktadırlar.

Tablo: 3

Finlandiya Yerel Yönetimlerin Borç Toplamı ve Borçlarının Yapısı (Milyon EURO)

\begin{tabular}{|l|c|c|c|c|c|c|}
\hline & Toplam Borçlar & Para Piyasası & Bono-Tahvil & Kisa Dönem & Uzun Dönem & GSMH Oranı \\
\hline $\mathbf{2 0 1 0}$ & 11.958 & 1.239 & 693 & 126 & 9.900 & 5,7 \\
\hline $\mathbf{2 0 1 1}$ & 11.892 & 1.039 & 579 & 52 & 10.222 & 5,8 \\
\hline $\mathbf{2 0 1 2}$ & 12.813 & 1.127 & 588 & 133 & 10.965 & 6,5 \\
\hline $\mathbf{2 0 1 3}$ & 14.974 & 1.672 & 718 & 171 & 12.413 & 7,4 \\
\hline $\mathbf{2 0 1 4}$ & 16.535 & 1.833 & 619 & 189 & 13.894 & 8 \\
\hline $\mathbf{2 0 1 5}$ & 17.339 & 1.910 & 592 & 257 & 14.580 & - \\
\hline
\end{tabular}

Kaynak: StatisticsFinland's PX-Web databases, 29.07.2015,

$<$ http://pxnet2.stat.fi/PXWeb/pxweb/en/StatFin/StatFin jul/?rxid=9610b853-0a5a-4963-b833-6853e92bd6c7>.

42010 ve 2012 yll verileri Finlandiya Yerel ve Bölgesel Yönetimler Birliğinin $<$ http://www.kunnat.net/en/authorities/municipal-finances/Documents/Annex\%202_pdf> $<$ http://www.kunnat.net/en/authorities/municipal-finances/Documents/Annex\%205.pdf> uzantıll internet adreslerinden temin edilmiştir. 28.07.2015.

5 Örneğin İsveç'te 2007 yılında 330 Milyar SEK iken, 2013 yılında 480 milyar SEK'e yükselmiş ve yaklaşık\%50 artış olmuştur (KOMMUNINVEST, 2014: 11). 


\subsubsection{Finlandiya Belediye Finansman Şirketi}

Finlandiya Belediye Finansman Şirketi (Municipality Finance Plc-MUNIFIN) 1990 yılında Yerel Yönetimler Emeklilik Fonu (Local Government Pensions Institution) tarafindan kurulmuş olup, 2001 yılında Belediye Konut Finansman Şirketi (Municipal Housing Finance Plc) ile birleşmiştir (Brady vd., 2015: 74). Hâlihazırda MUNIFIN'in \%53'ü yerel yönetimlerin veya onların kurdukları şirketlerin, \%16'sı Finlandiya Devleti'nin ve \%31'i de bir kamu kurumu emeklilik fonu olan KEVA'nındır.

MUNIFIN'in son 5 yıldaki mali yapısına ilişkin veriler aşağıda yer alan tabloda verilmektedir. Tablodan da görüleceği üzere MUNIFIN özsermaye yerine borçlanma aracı ihracı yoluyla finansman sağlayan, bu itibarla özkaynak karlılı̆̆ 1 yüksek, düzenli olarak yerel yönetimlere kullandırdığı kredi portföyü artan bir yapıya sahiptir.

Tablo: 4

MUNIFIN'e İlişkin Temel Veriler ve Oranlar (Milyon EURO)

\begin{tabular}{|l|c|c|c|c|c|}
\hline & $\mathbf{2 0 1 0}$ & $\mathbf{2 0 1 1}$ & $\mathbf{2 0 1 2}$ & $\mathbf{2 0 1 3}$ & $\mathbf{2 0 1 4}$ \\
\hline A. Özsermaye & 245,9 & 288,4 & 428,9 & 509 & 623 \\
\hline B. Belediye ve Diğer Kamu Kurumlarına Krediler Toplamı & 11.698 & 13.625 & 15.700 & 17.801 & 19.205 \\
\hline C. Aktif Toplam & 20.047 & 23.841 & 25.560 & 26.156 & 30.009 \\
\hline D. Faiz Gelirleri & 201 & 328 & 275 & 180 & 212 \\
\hline E. Faiz Giderleri & 122 & 234 & 133 & 30 & 52 \\
\hline F. İhraç Edilen Borçlanma Araçları & 14.879 & 17.187 & 18.798 & 20.269 & 23.230 \\
\hline G. Net Kar & 43 & 50 & 104 & 124 & 115 \\
\hline H. Çalışan Sayısı & 61 & 67 & 72 & 83 & 90 \\
\hline Özsermaye /Krediler (B/A) & 0,02 & 0,02 & 0,03 & 0,03 & 0,03 \\
\hline Net Kar/Özsermaye (G/A) & 0,17 & 0,17 & 0,24 & 0,24 & 0,18 \\
\hline
\end{tabular}

Kaynak: MUNIFIN 2011-2014 yılları yıllık faaliyet raporları kullanılarak yazarlar tarafindan oluşturulmuştur. $<$ https://www.munifin.fi/about-us/key-figures-0>.

Tablo: 5

MUNIFIN Toplam Kredilerin Kurumlar Arasındaki Dağılımı (\%)

\begin{tabular}{|l|c|c|c|c|c|}
\hline & $\mathbf{2 0 1 0}$ & $\mathbf{2 0 1 1}$ & $\mathbf{2 0 1 2}$ & $\mathbf{2 0 1 3}$ & $\mathbf{2 0 1 4}$ \\
\hline Yerel Yönetimler & NA & 43 & 42 & 41 & 41 \\
\hline Yerel Yönetim Şirketleri & NA & 39 & 41 & 41 & 41 \\
\hline Konut Şirketleri & NA & 13 & 12 & 12 & 13 \\
\hline Yerel Yönetim Birlikleri & NA & 5 & 5 & 6 & 5 \\
\hline
\end{tabular}

Kaynak: MUNIFIN 2011-2014 ylları yıllık faaliyet raporları kullanılarak yazarlar tarafindan oluşturulmuştur. $<$ https://www.munifin.fi/about-us/key-figures-0>.

MUNIFIN'ın fon sağladığı ülkeler, para birimleri, kredi verdiği kuruluşlara ilişkin bilgiler ise aşağıdaki grafikler ve tabloda yer almaktadır. MUNIFIN yerel yönetimler ile şirketlerine yaklaşık 9 milyar EURO kaynak aktarmış olup, bu yerel yönetimlerin toplam borçlarının \%50'sinden fazlasına tekabül etmektedir. Fonlama kaynaklarına bakıldığında daha çok uluslararası kaynaklara başvurulduğu ve özellikle Asya Pasifik bölgesinden fon 
sağlandığı görülmektedir. Japonya fon sağlanan ülkeler arasında önemli bir yere sahiptir. 2012 yılında toplam fonların \%51 (MUNIFIN, 2013: 8), 2011 yılında ise \%48'i (MUNIFIN, 2012: 8) Japonya'dan sağlanmıştır.

\section{Grafik: 1}

MUNIFIN Fon Kaynaklarının Bölgesel Dağılımı
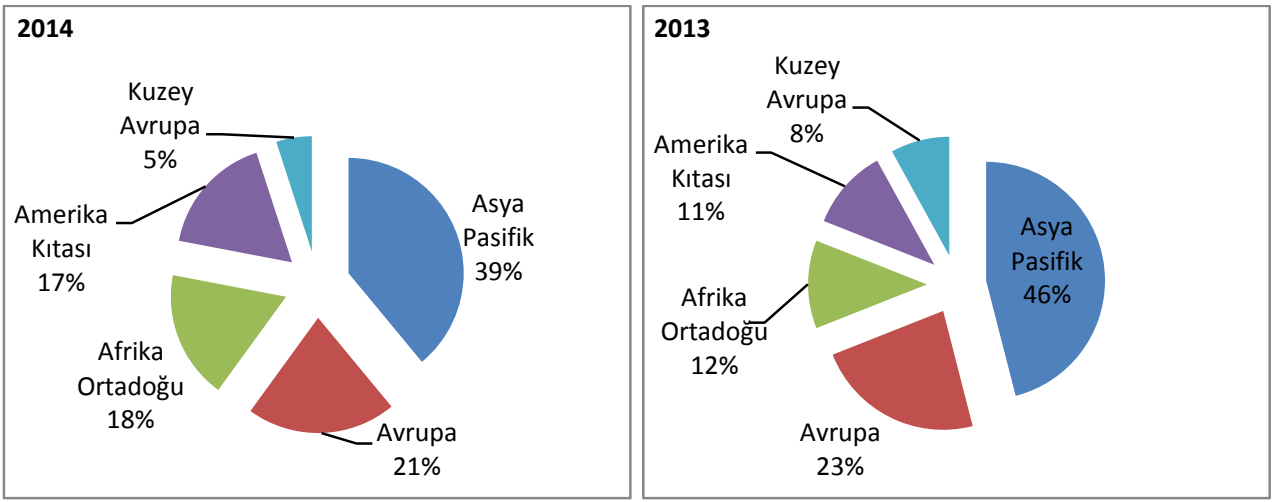

Kaynak: MUNIFIN of Finland, 2015: 13; 2014: 9.

MUNIFIN'in borçlanmaları Yerel Yönetimler Garanti Kurumu (MunicipalGuarantee Board-MGB) tarafindan garanti edilmekte olup, bu sayede MUNIFIN tarafından ihraç edilen borçlanma araçları sermaye yeterliliği uygulamalarında risksiz olarak kabul edilmektedir. 1996 yılında kurulan MGB'ye yerel yönetimlerin \%98,4'ü üye durumdadır. MUNIFIN tarafından yapılan borçlanmalarda bir temerrüt durumunda üye yerel yönetimler nüfusları oranında söz konusu temerrüt tutarından yükümlü olmaktadırlar (Brady vd., 2015: 76).

MUNIFIN tarafından verilen borçların vadesine bakıldığında ise 2014 yılı itibarıyla verilen kredilerin \%6's1 1 y1l ve altında, \%31'i 1 ila 5 y1l arasında, \%21'i 5 ila 10 yıl arasında, \%39'u ise 10 yıl ve üzerindedir. Söz konusu vadeler MUNIFIN'in borçlanma araçları ihraç vadeleriyle de büyük ölçüde uyumludur (MUNIFIN, 2015: 55). MUNIFIN'in borçlanma maliyetlerine bakıldığında 14 Ocak 2015'te 1 milyar USD tutarında altı aylık \%1.5 kupon ödemeli bir tahvil ihrac1, 16 Eylül 2014 ve 14 Mayıs 2014'te 1'er milyar USD tutarında sırasıyla altı aylık \%1,125 ve yıllık \%1,75 kupon ödemeli, 5 Eylül 2013'te 1 milyar UDS tutarında yıllık \%1,25 kupon ödemeli tahvil ihraçları gerçekleştirmiştir (MUNIFIN, 2015-1: 19-23). Benzer dönemlerde Finlandiya Hazinesi tarafından yapılan borçlanmalara 
bakıldığında $^{6}$, Mayıs 2015 tarihinde 5 y1l vadeli 1,5 milyar USD tutarında altı aylık \%1 kupon ödemeli bir tahvil ihracı, Eylül 2014'te 1,5 milyar USD tutarında yıllık 1,75 kupon ödemeli tahvil ihracı gerçekleştirilmiştir. Finlandiya Hükümeti ile aynı kredi notuna sahip olan MUNIFIN'in borçlanma maliyeti de, Finlandiya Hazinesi'nin 50 baz puan üzerinde gerçekleşmektedir ${ }^{7}$.

Sonuç olarak MUNIFIN uluslararası sermaye piyasalarından tahvil ihraç etmek suretiyle borçlanarak yerel yönetimlere düşük maliyetle ve uzun vadeli finansman sağlayan, borçlanmaları MGB tarafından garanti edilen ve yerel yönetimlerin toplam borç yükünün yarısından fazlasını sağlayan bir yerel yönetim bankasıdır.

\subsection{Japonya}

Japonya' da yerel yönetimler öncelikli olarak genel ve özel yerel yönetim birimleri olmak üzere ikiye ayrılmaktadır. Genel yerel yönetimler bölgesel yönetim birimi olarak valilikler (prefectures) ve yerel yönetim birimi olarak belediyeler (municipalities) olmak üzere iki kademeli bir yapıya sahiptirler. Özel yerel yönetim birimleri ise özel bölge yönetimleri, yerel yönetim birlikleri, yerel kalkınma birlikleri ve birimleri olarak sinıflandırılabilir (Clair, 2010: 6). Japonya'da belediyeler ve valilik toplamı olarak yerel yönetimlerin gelir ve giderlerine ilişkin bilgiler aşağıdaki tablolarda yer almaktadır. Tablodan da görüldüğü üzere tahvil ile borçlanma yoluyla gelir elde edilmesi de yıllara göre değişmekle birlikte \%11-13 arasında değişmekte ve yerel yönetimlerin gelirleri içinde önemli bir yere sahip bulunmaktadır. Yerel yönetimlerin giderleri incelendiğinde ise borç anapara ve faiz ödemelerinin toplam harcamalar içerisinde \%11-12 aralığında olduğu görülmektedir.

Japonya İçişleri ve İletişim Bakanlığı tarafindan yerel yönetimlerin borç servis oranları düzenli olarak takip edilmekte ve belirlenen sınırın (borç ödeme servis oranı \%18) aşılması durumunda yeni tahvil ihracına izin verilmemektedir (MOCHIDA, 2008: 3). Yerel yönetimlerin borçlanma limitleri ise "Yerel Yönetimler Borçlanma Programı" ile her yıl belirlenmekte ve yerel yönetimler bu program çerçevesinde borçlanmalarını gerçekleştirebilmektedirler. Tahvil ihraçları doğrudan yerel yönetimler tarafindan yapılabilmekte olup, merkezi hükümet tarafından yapılan ihraçların yerel yönetimlere devredilmesi de bir yöntem olarak uygulanmaktadır (MOCHIDA, 2008: 4).

6 Finlandiya Hazine'sinin <http://www.treasuryfinland.fi/en-US/Funding_and_cash_management/news $>$ uzantılı web adresinden temin edilmiştir. Erişim tarihi 03.08.2015.

7 Finlandiya Hazine'si tarafindan yapılan borçlanmalarda yüklenici bankalar tarafindan yapılan tekrar satım fiyatı (re-offerprice) MUNIFIN borçlanmasina göre yüksek verilmekte, böylece yüklenicilerin Hazine'ye ödedikleri ihraç tutarı yüksek olmakta, kupon ödemeleri aynı gibi görünse dahi, bu Hazine lehine bir avantaj sağlamaktadır. 
Tablo: 6

Japonya Yerel Yönetimler Toplam Gelirleri ve Ana Kalemler (Milyar ¥)

\begin{tabular}{|l|r|r|r|r|r|r|}
\hline & $\mathbf{2 0 0 0}$ & $\mathbf{2 0 0 5}$ & $\mathbf{2 0 0 9}$ & $\mathbf{2 0 1 0}$ & $\mathbf{2 0 1 1}$ & $\mathbf{2 0 1 2}$ \\
\hline Yerel Vergi Gelirleri & 35.546 & 34.804 & 35.183 & 34.316 & 34.171 & 34.460 \\
\hline Yerel Tahsis Vergisi & 21.776 & 16.959 & 15.820 & 17.194 & 18.752 & 18.290 \\
\hline Merkezi Yönetim Transferleri & 14.454 & 11.889 & 16.840 & 14.306 & 16.031 & 15.459 \\
\hline Yerel Transfer Vergisi & 620 & 1.849 & 1.297 & 2.069 & 2.170 & 2.271 \\
\hline Özel Yerel Yardımlar & 914 & 1.518 & 462 & 383 & 364 & 127.5 \\
\hline Yerel Tahviller & 11.116 & 10.376 & 12.396 & 12.970 & 11.760 & 12337 \\
\hline Dĭ̌er Gelirler & 15.849 & 15.541 & 16.368 & 16.274 & 16.822 & 16.898 \\
\hline Toplam & 100.275 & 92.936 & 98.366 & 97.512 & 100.070 & 99842 \\
\hline
\end{tabular}

Kaynak: Statistics Japan web sayfasinin <http://www.stat.go.jp/english/data/nenkan/1431-05.htm> uzanttll internet adresinden temin edilmiștir. Erişim tarihi: 07.08.2015.

Tablo: 7

Japonya Yerel Yönetimler Toplam Giderleri ve Ana Kalemler (Milyar ¥)

\begin{tabular}{|c|c|c|c|c|c|c|}
\hline & \begin{tabular}{|l|}
2007 \\
\end{tabular} & 2008 & \begin{tabular}{|l|}
2009 \\
\end{tabular} & 2010 & 2011 & 2012 \\
\hline Kamu Refah Harcamaları & 16.976 & 17.821 & 19.768 & 21.316 & 23.182 & 23.152 \\
\hline Eğitim Harcamaları & 16.431 & 16.146 & 16.438 & 16.446 & 16.176 & 16.148 \\
\hline Genel Yönetim Harcamaları & 8.906 & 8.919 & 10.718 & 10.000 & 9.346 & 9.962 \\
\hline Borç Anapara ve Faiz Harc. & 13.025 & 13.159 & 12.884 & 12.979 & 12.959 & 13.009 \\
\hline Sağlık Harcamaları & 5.436 & 5.390 & 5.971 & 5.812 & 6.743 & 5.993 \\
\hline Ticari ve Sanayi Harcamalar & 4.949 & 5.327 & 6.575 & 6.398 & 6.548 & 6.207 \\
\hline Tarım, Orman ve Balıkçılık Harc. & 3.452 & 3.286 & 3.553 & 3.246 & 3.207 & 3.181 \\
\hline İnşaat Harcamaları & 13.390 & 12.871 & 13.292 & 11.959 & 11.285 & 11.242 \\
\hline Diğer Harcamalar & 6.582 & 6.772 & 6.907 & 6.619 & 7.557 & 7.524 \\
\hline Toplam & 89.147 & 89.691 & 96.106 & 94.775 & 97.003 & 96.418 \\
\hline
\end{tabular}

Kaynak: Statistics Japan web sayfasinin <http://www.stat.go.jp/english/data/nenkan/1431-05.htm> uzanttll internet adresinden temin edilmiştir. Erişim tarihi: 07.08.2015.

Tablo: 8

2005-2014 Yılları Arasında Yerel Yönetim Tahvil Talebi Dağılımı (Milyar Yen)

\begin{tabular}{|l|c|c|c|c|c|c|c|c|c|c|}
\hline & $\mathbf{2 0 0 5}$ & $\mathbf{2 0 0 6}$ & $\mathbf{2 0 0 7}$ & $\mathbf{2 0 0 8}$ & $\mathbf{2 0 0 9}$ & $\mathbf{2 0 1 0}$ & $\mathbf{2 0 1 1}$ & $\mathbf{2 0 1 2}$ & $\mathbf{2 0 1 3}$ & $\mathbf{2 0 1 4}$ \\
\hline Merkezi Hükümet & 4.720 & 3.880 & 3.280 & 3.240 & 4.264 & 4.339 & 3.731 & 3.619 & 3.576 & 3.333 \\
\hline JFM & 1.533 & 1.406 & 1.350 & 1.333 & 1.883 & 2.159 & 1.893 & 1.952 & 1.960 & 2.017 \\
\hline Halka Arzlar & 3.300 & 3.500 & 3.400 & 3.400 & 3.670 & 4.300 & 4.200 & 4.440 & 4.440 & 4.260 \\
\hline Diğer Özel Sektör & 6.311 & 5.191 & 4.481 & 4.505 & 4.767 & 5.100 & 3.910 & 3.529 & 3.395 & 3.220 \\
\hline
\end{tabular}

Kaynak: Japonya Yerel Yönetimler Tahvil Birliği (JLGB),

$<$ http://www.chihousai.or.jp/english/07/pdf/2014_01_mic.pdf>, 20.08.2010.

Yerel yönetimler kamu sektöründe merkezi hükümet ve Japonya Yerel Yönetim Bankası'ndan (Japan Finance Organization for Municipalities - JFM), özel sektörde ise tahsisli satışlar veya halka arz yoluyla borçlanma gerçekleştirmektedir. Birden fazla yerel yönetimin bir araya gelmesiyle de tahvil ihracı gerçekleştirilebilmektedir (Joint Local 
Government Bond) ${ }^{8}$. 2005-2014 yılları arasında gerçekleştirilen borçlanmalar ve bunlara kaynak sağlayan kurumlara ilişkin tablo yukarıda yer almaktadır. Söz konusu tablodan görüldüğü üzere yerel yönetim tahvillerine olan talebin $\% 60$ ve üzeri özel sektör kaynaklı olup, JFM'nin tahvil talebindeki rolü \%10'lardan \%16'lere yükselmiştir'9.

\subsubsection{Japonya Yerel Yönetim Bankası}

1 Haziran 1957 tarihinde sermayesi merkezi yönetime ait olarak kurulan Japonya Yerel Yönetim Finansman Kuruluşu'nun (Japan Finance Organizaton for Municipal Enterprises), sermaye dışında kalan varlık ve yükümlülükleri 1 Ağustos 2008 tarihinde kurulan ve semayesi yerel yönetimlere ait olan Japonya Yerel Yönetim Bankası'na (Japan Finance Organizaton for Municipalities - JFM) devredilmiş ve JFM borç verme kapasitesi yükseltilerek 1 Haziran 2009 tarihinde faaliyetlerine başlamıştır (JLGB, 2014: 14).

Mart 2014 itibarıyla 1,386 milyar USD özsermayesiolan şirket, Japonya devleti ile aynı derecelendirme notuna sahiptir (S\&P: AA-, Moodys: Aa3). Şirketin yerel yönetimlere kullandırdığı kredi toplamı 224 milyar USD olup, piyasada 189 milyar USD tutarında borçlanma aracı bulunmakta, 33 milyar USD'yi ise faiz oranlarındaki değişmelere karşı rezerv olarak tutmaktadır (JLGB, 2014: 3).

Japonya'da yerel yönetimlerin yıllık borçlanma limitleri her yıl merkezi hükümet tarafından oluşturulan Yerel Yönetimler Borçlanma Programı çerçevesinde belirlenmekte olup, bu borçlanmaların hangi kaynaklardan sağlanacağı da yine bu programda belirlenmektedir. Bu çerçevede JFM, yerel yönetimlerin borçlanmasının 2013 yılında 21 ve 2014 yılında da 20 milyar USD olmak üzere yaklaşık \%16'sını karşılamıştır (JLGB, 2014: 23).

Banka'nın verdiği bu kredileri ulusal ve uluslararası piyasalardan tahvil ihraç etmek suretiyle fonladığ́ görülmektedir. Aşağıdaki tabloda Banka’nın 2011-2013 yılları arasında gerçekleştirdiği tahvil ihraçlarına ilişkin ayrıntılı bilgiler yer almaktadır. Banka yurtdışında hazine garantili tahvil ihraç etmemekte, toplam borçlanma tutarlarının yaklaşık \%10’unu yurtdışı piyasalardan sağlamaktadır.

2011 yılında halk arz yoluyla yapılan ihraçların yaklaşık \%17'si 20 yıl, \%40’’1 10 yıl, \%8'i ise 5 yıl vadeye sahiptir. Tahsisli satışla yapılan yaklaşık 3 milyar USD tutarındaki tahvil ihracının vadesi ise 10 yıldır. Hazine garantili tahvillerin vadesi incelendiğinde \%75'inin vadesinin 10 yıl olduğu görülmektedir (JFM, 2012: 18-19). 2013 y1lı için ise 
tahsisli satışların vadesinin 10 yıl, halk arz yoluyla yapılan ihraçların yaklaşık \%12'si 20 yıl, \%41'inin 10 yıldır. Hazine garantili tahvillerin \%50'sinin vadesinin 10 yıl olduğu görülmektedir (JFM, 2014: 12).

Tablo: 9

JFM Kaynak Oluşturma (Fonlama) Bilgileri (Milyar USD)

\begin{tabular}{|c|c|r|r|r|r|}
\hline & & $\mathbf{2 0 1 1}$ & $\mathbf{2 0 1 2}$ & $\mathbf{2 0 1 3}$ & $\mathbf{2 0 1 4} *$ \\
\hline \multirow{3}{*}{ Hazine Garantisi Olmayan Tahviller } & Halka Arz & 9,2 & 9,4 & 9,8 & 8,6 \\
\cline { 2 - 5 } & Tahsisli Satış & 2,9 & 2,9 & 2,9 & 2,9 \\
\cline { 2 - 5 } & Yurtdıșı Satışar & 0,7 & 2,2 & 3,2 & 2,1 \\
\hline Toplam & & 12,7 & 14,5 & 15,9 & 13,6 \\
\hline \multirow{2}{*}{ Hazine Garantisi Olan Tahviller } & Ulusal Tahviller & 6,9 & 10 & 12,4 & 6,1 \\
\cline { 2 - 5 } & Uluslararası Tahviller & - & - & - & - \\
\hline Toplam & & 6,9 & 10 & 12,4 & 6,1 \\
\hline İlgili Yıl Toplam Borçlanma Aracı İhracı & & $\mathbf{1 9 , 6}$ & $\mathbf{2 4 , 5}$ & $\mathbf{2 8 , 2}$ & $\mathbf{1 9 , 7}$ \\
\hline Toplam Tahvil Bakiyesi & & $\mathbf{1 7 6 , 4}$ & $\mathbf{1 8 1 , 3}$ & $\mathbf{1 8 8 , 6}$ & - \\
\hline
\end{tabular}

Kaynak: JFM, <http://www.jfm.go.jp/en/investors/issue.html>, 25.08.2015.

*Planlanan

Borçlanma maliyetleri, borçlanmaların Hazine borçlanmaları ile karşılaştırılmasına ilişkin grafik aşağıda yer almaktadır. JFM'nin borçlanma maliyeti \%1'in altında seyretmekte olup, Japonya Hazinesi'nden uzun bir dönem 2,5 baz puan daha yüksek borçlanırken, son yıllarda bu oran 10-12 baz puan arasında değişmektedir.

\section{Grafik: 2}

\section{JFM Borçlanma Maliyeti - Japon Hazinesi Borçlanması}

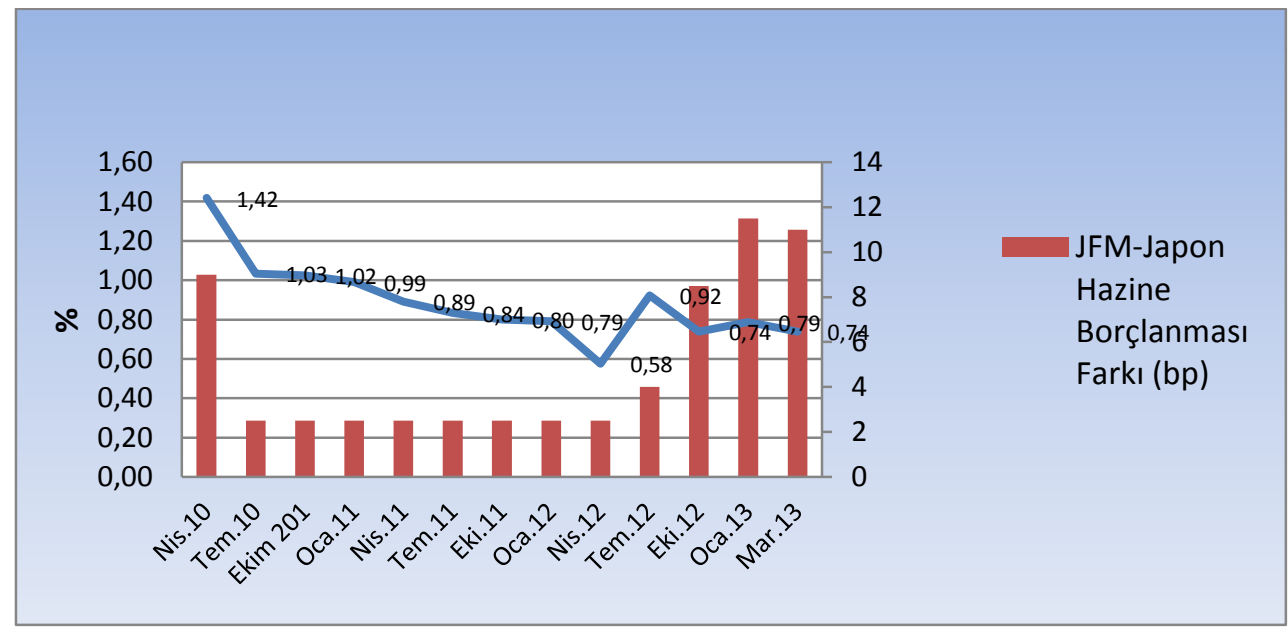

Kaynak: JFM, Annual Report 2014, <http://www.jfm.go.jp/en/investors/financial.html\#annual>, 25.08.2015, 13. 
Aşağıdaki grafikte ise JFM standart borç verme faiz oranları yer almaktadır. Banka borçlanma maliyetlerine yaklaşık \%1 ilave ederek borç verme işlemini gerçekleştirmektedir. Diğer taraftan, Banka tarafindan \%0,35 oranında indirim yapılmak suretiyle belirli projeler için kredi verebilmektedir (JFM, 2014: 23). Söz konusu kredilerin vadesi çok büyük oranda 5 yıl geri ödemesiz dönem olmak üzere 20-30 yıl arasında değişmektedir (JFM, 2014: 21).

Grafik: 3

JFM Standart Borç Verme FaizOranı

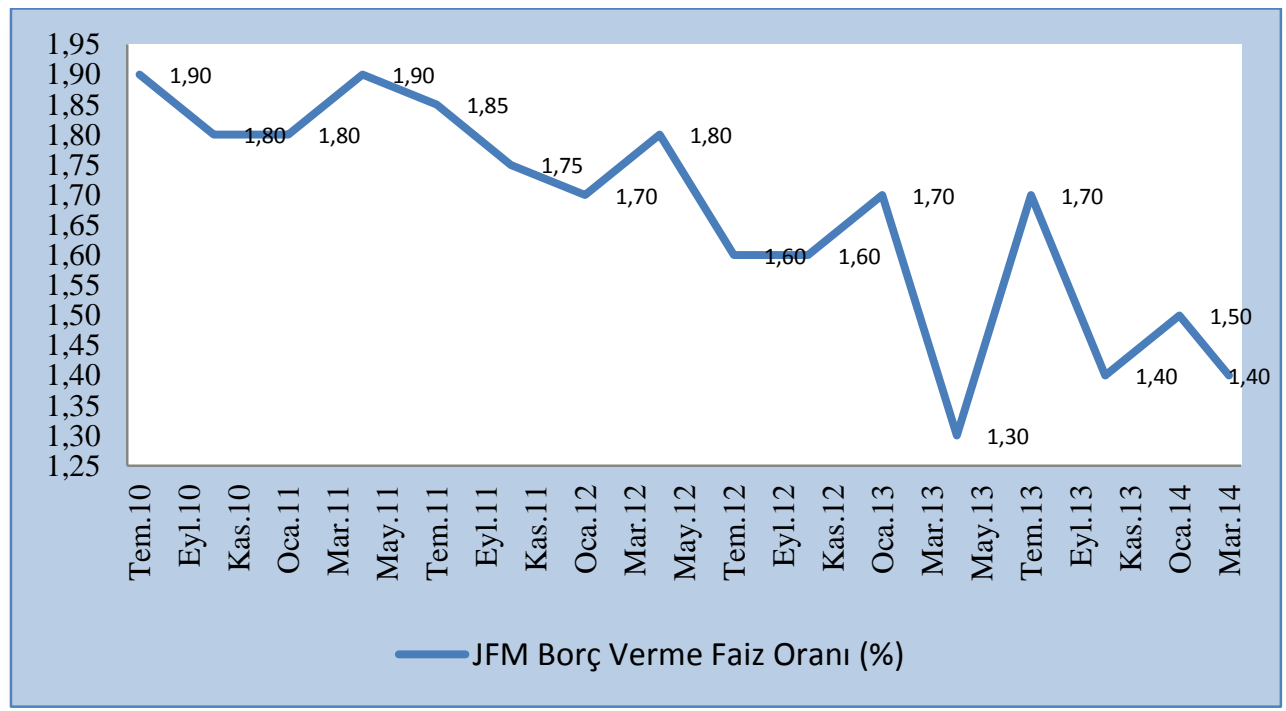

Kaynak: JFM, Annual Report 2014, <http://www.jfm.go.jp/en/investors/financial.html\#annual>, 25.08.2015, 22.

2013 yılı itibarıla Banka'nın toplam 4.449 milyon USD gelirinin \%99,3’ü faiz gelirinden oluşurken, 2,624 milyar USD giderin \%96,5'i faiz giderlerinden oluşmaktadır. Dolayısıyla Banka'nın giderleri arasında genel yönetim, personel ve operasyonel giderler çok düşük düzeyde kalmaktadır.

Sonuç olarak JFM, 224 milyar USD büyüklüğünde kredi stoku bulunan, yerel yönetimler için merkezi hükümet tarafından her yıl belirlenen borçlanma limitleri çerçevesinde yerel yönetimlerin toplam borçlanma miktarlarının yaklaşık \%16'sını karşılayan, borç verme kaynaklarını ulusal ve uluslararası piyasalarda gerçekleştirdiği tahvil ihraçları ile sağlayan, borçlanma faiz oranı merkezi yönetimin sadece 12 baz puan üzerinde olan ve borçlarının vadesi 20-30 yıl arasında değişen bir yerel yönetim bankası olarak faaliyetlerini sürdürmektedir. 


\section{Türkiye’de İller Bankası ve Yerel Yönetim Bankacılı̆ğ}

İller Bankası il özel idareleri, belediyeler ve bağlı kuruluşları ile münhasıran bunların üye oldukları mahalli idare birliklerinin finansman ihtiyacını karşılamak, mahalli müşterek hizmetlere ilişkin projeler geliştirmek, danışmanlık ve denetim hizmeti vermek, merkezi hükümetin yerel yönetimlere yaptığı her türlü kaynak transferine aracılık etmek ve kalkınma ve yatırım bankacılığı işlevlerini yerine getirmek amacıyla kurulmuş, ortakları da bu idareler olan bir kalkınma ve yatırım bankasıdır.

İller Bankası bu amaçlarını temelde 3 fonksiyonu icra ederek gerçekleştirmektedir. Bunlar aracılık, yatırım ve danışmanlık ile kredi fonksiyonlarıdır (Berk, 2003: 78; Şimşek, 2007: 32-33). Banka merkezi yönetimden yerel yönetimlere aktarılan transferlerde aracılık görevi yapmaktadır. Yerel yönetimlerin yatırımları ile makine ve teçhizat alımlarında kendi özkaynaklarından veya yabancı kaynaklardan kredivermektedir. Son olarak Banka, yatırım ve danışmanlık fonksiyonu çerçevesinde kentlerin altyapı plan ve projelerini, su dağıtımı, su arıtma, kanalizasyon, atıksu arıtma, sosyal amaçlı projelerini hazırlamak ve bu projelerin anahtar teslimi gerçekleştirilmesini teminen ihaleler açmak, değerlendirmek, sözleşmeler imzalamaktadır (Berk, 2003: 78).

Yukarıda yer alan fonksiyonlardan da görüleceği üzere İller Bankası dünyada görülen yerel yönetim bankacılık uygulamalarından farklılık arz etmektedir. Dünya uygulamasında bu bankaların temel görevi kredi sağlamaktır. Ülkemizde de 1933-1944 yılları arasında İller Bankası'nın dönüştüğü kurum olan Belediyeler Bankası'nın temel amacı bu olmasına rağmen, 1945 yılında İller Bankası kurularak kredi fonksiyonuna ilave olarak yatırım ve danışmanlık fonksiyonunu da üstlenmiştir. Banka, kredilerin yatırımlara dönüşmesinde veya krediden bağımsız olarak teknik ekipman ve kadrosuyla fiili olarak çalışarak yerel yönetimlerin temel fonksiyonlarının yerine getirilmesinde aktif görev üstlenmektedir (Kestane, 1996: 29).

Banka'nın teşkilat yapısı incelendiğinde bankacılık ile ilgili 2 Daire Başkanlığı'nın, yatırım ve danışmanlı hizmetlerine ilişkin 7 Daire Başkanlığı'nınbulunduğu; 2014 yılı faaliyet raporunda (Iller Bankası, 2015: 51) yer alan personel bilgileri incelendiğinde de personelin \%47'sinin teknik personel olduğu, kalan personelin yaklaşık \%48'inin de temelde yatırım ve buna bağlı teknik hizmetler ve uygulamaları yerine getiren bölge ofislerinde istihdam edilen personel olduğu görülmektedir.

\section{1. İller Bankasının Mali Yapısı}

Banka'nın ödenmiş sermayesi 9,4 milyar TL., öz sermayesi ise 11,3 milyar TL.'dir. Bankanın anasermaye kaynağı yerel yönetimlere aktarılacak vergi gelirleri paylarının toplamı üzerinden aylık olarak kesilen \%2'lik komisyondur. Bu nedenle banka sermayesi paylara bölünmemiştir. Dolayısıyla tüm yerel yönetimler aynı anda Banka'da ortaklık hakkına sahiptirler. 
Bankanın 2009-2014 yılları arasında krediler, özkaynaklar, karlılık ve aktif toplamları ve bunların kendi içindeki oranlarına ilişkin veriler aşağıdaki tabloda yer almaktadır. Söz konusu tablodan da görüleceği üzere Banka kullandırmış olduğu kredileri çok büyük oranda özkaynaklarından sağlamaktadır. Krediler/özkaynaklar oranı incelenen dönemde 1'e yakın seyretmektedir.

Banka Dünya Bankası'ndan, Japonya Uluslararası İşbirliği Ajansı (JICA)'dan ve Avrupa Yatırım Bankası (AYB)'ndan 2014 yılı için yaklaşık 615 milyon TL., 2013 yılı için 522 milyon TL. kaynak temin etmiş olup, yerel yönetimlere kullandırılan 11,5 milyar TL.'lik kredi içerisinde bu tutar da yer almaktadır (İller Bankası, 2013: 69; 2014: 65). Dolayısıyla merkezi hükümet aracılığıyla sağlanan uluslararası kuruluş kredileri dışında bankanın ortaklarına kredi vermek ve finansman sağlamak adına para ve sermaye piyasası kaynaklarını kullandığını ve dolayısıyla yerel yönetim bankacılığı faaliyeti yaptığını söylemek zor görünmektedir.

Tablo: 10

\section{İller Bankası Tarafından Verilen Krediler, Özkaynakar, Yabancı Kaynaklar, Aktif Toplamı ve Oranlar (Bin TL.)}

\begin{tabular}{|c|c|c|c|c|c|c|}
\hline & $\mathbf{2 0 0 9}$ & $\mathbf{2 0 1 0}$ & $\mathbf{2 0 1 1}$ & $\mathbf{2 0 1 2}$ & $\mathbf{2 0 1 3}$ & $\mathbf{2 0 1 4}$ \\
\hline Krediler & 6.175 .058 & 6.669 .608 & 7.784 .913 & 8.949 .749 & 11.358 .967 & 11.477 .528 \\
\hline Özkaynaklar & 6.224 .380 & 7.376 .545 & 8.439 .629 & 9.306 .492 & 10.191 .035 & 11.334 .883 \\
\hline Aktif Toplam & 8.008 .539 & 9.677 .150 & 11.392 .823 & 12.641 .596 & 14.713 .988 & 16.297 .141 \\
\hline Net Dönem Karı & 345.115 & 240.289 & 246.899 & 291.588 & 327.120 & 524.543 \\
\hline Serm. Ytrl.Stdnrt. Oranı & 66,44 & 73,14 & 64,93 & 62,53 & 59,87 & 66,02 \\
\hline Krediler/Özkaynaklar & 0,99 & 0,90 & 0,92 & 0,96 & 1,11 & 1,01 \\
\hline Krediler/Aktif Toplam & 0,77 & 0,69 & 0,68 & 0,71 & 0,77 & 0,70 \\
\hline Özkaynaklar/Aktif Toplam & 0,78 & 0,76 & 0,75 & 0,74 & 0,69 & 0,69 \\
\hline Özkaynak Karlığı & 5,54 & 3,26 & 2,89 & 3,13 & 3,21 & 4,63 \\
\hline
\end{tabular}

Kaynak: Illler Bankası 2009-2014 yilları faaliyet raporları, <www.ilbank.gov.tr >.

2013 yılı sonu itibarıyla mahalli idarelerin toplam mali borç stoğu 26 milyar TL iken, İller Bankası tarafından verilen kredi tutarı 11,4 milyar TL.' dir. İller Bankası mahalli idarelerin finansman ihtiyacının \%44'ünü karşılamıştır. 2014 y1lı için bu rakamlar 27,1 milyar TL, 11,5 milyar TL. ve oran da \%42'dir ${ }^{10}$.Aynı oran 2010 yılında \%52 olup, İller Bankası tarafından yerel yönetimlere sağlanan kredilerde oransal olarak düzenli bir azalış meydana gelmektedir. Banka'nın hiç faiz gideri bulunmazken, temel gideri personel gideri, gelirleri ise verdiği kredilerden aldığı faizler ile bankalarda değerlendirdiği nakitlerden elde edilen faiz gelirleri oluşturmaktadır.

10 Toplam borç rakamlarl <www.muhasebat.gov.tr> adresinde bulunan mahalli idarelerin 2013-2014 yıllarl bilançolarından, Illler Bankası verileri ise Banka'nın 2013-2014 yılları faaliyet raporlarından derlenmiştir. 
Tablo: 11

Iller Bankası Gelir-Gider Kalemleri (Bin TL. \%)

\begin{tabular}{|l|c|c|c|c|c|c|}
\hline & $\mathbf{2 0 0 9}$ & $\mathbf{2 0 1 0}$ & $\mathbf{2 0 1 1}$ & $\mathbf{2 0 1 2}$ & $\mathbf{2 0 1 3}$ & $\mathbf{2 0 1 4}$ \\
\hline Kredilerden Alınan Faizler & 503.333 & 361.239 & 373.378 & 435.591 & 555.660 & 745.853 \\
\hline Bankalardan Alınan Faizler & $77.185^{*}$ & $105.039^{*}$ & 174.404 & 210.739 & 129.012 & 152.827 \\
\hline Diğer Faaliyet Gelirleri & 49.110 & 35.912 & 38.389 & 64.809 & 169.083 & 246.339 \\
\hline Faiz Giderleri & 1 & 49 & 29 & 23 & 15 & 1.752 \\
\hline Diğer Faaliyet Giderleri & 184.552 & 201.928 & 263.812 & 290.824 & 327.777 & 384.309 \\
\hline
\end{tabular}

Kaynak: Iller Bankast 2009-2013 yılları faaliyet raporlarl <www.ilbank.gov.tr>, <www.muhasebat.gov.tr>.

*Söz konusu tutarlara para piyasasından alınan sırasıla 23.381 bin TL ve 28.619 bin TL. dahil edilmiştir. Zira bu tutar Banka'nın tuttuğu nakdin değerlendirilmesinden elde edilmiş ve diğer finansal kurumlara borç verilmek suretiyle elde edilmiştir.

\section{2. İller Bankası ve Yerel Yönetimler Arasındaki Mali İlişsiler}

İller Bankası ile yerel yönetimler arasındaki mali ilişkiler kredi ilişkisi, ortaklık ilişkisi ve merkezi yönetim kaynaklarının yerel yönetimlere aktarılmasındaki aracılık fonksiyonu olmak üzere 3 ana başlık altında sınıflandırılabilir.

İller Bankası ile yerel yönetimler arasında yatırım bankacılığı anlamındaki ilişki kredi iliş̧kisidir. Krediler ise mevcut durumda İller Bankası'nın kendi özkaynaklarından verdiği krediler ile uluslararası kuruluşlardan sağlanan krediler olmak üzere iki başlıkta sinıflandırılabilir.

Yıllar itibarıyla Banka tarafından yerel yönetimlere kullandırılan krediler ile Banka'nın kendisinin aldığı krediler aşağıdaki tabloda verilmektedir. Tablodan da görüleceği üzere Banka kullandırdığı kredilerin ancak \%5’ini (bazı dönemlerde \%2) yabancı kaynaklardan sağlamaktadır.

Tablo: 12

\section{İller Bankası Kredileri (Bin TL. \%)}

\begin{tabular}{|l|c|c|c|c|c|c|}
\hline & $\mathbf{2 0 0 9}$ & $\mathbf{2 0 1 0}$ & $\mathbf{2 0 1 1}$ & $\mathbf{2 0 1 2}$ & $\mathbf{2 0 1 3}$ & $\mathbf{2 0 1 4}$ \\
\hline Kullandırılan Krediler & 6.175 .058 & 6.669 .608 & 7.784 .913 & 8.949 .749 & 11.358 .967 & 11.477 .528 \\
\hline Alınan Krediler & 214.702 & 344.033 & 433.862 & 413.255 & 552.219 & 614.810 \\
\hline $\begin{array}{l}\text { Alınan Krediler/Kullandırılan } \\
\text { Kredi Oranı }\end{array}$ & 0,035 & 0,05 & 0,056 & 0,046 & 0,048 & 0,054 \\
\hline $\begin{array}{l}\text { Yerel Yönetimlerin Ticari Banka } \\
\text { Kredileri* }\end{array}$ & 5.709 .031 & 6.114 .408 & 6.554 .297 & 7.688 .485 & 11.443 .210 & 15.681 .885 \\
\hline
\end{tabular}

Kaynak: iller Bankası 2011-2014 yillarl faaliyet raporlar,, <www.ilbank.gov.tr>, 2009-2014 yillarl Mahalli İdareler Genel Faaliyet Raporlarl, <www.muhasebat.gov.tr>

*Yurtdışı borçlanmalar dahil edilmiştir. Toplam mali borçlarından İller Bankası kredileri çıkarılarak oluşturulmuştur.

Diğer taraftan yerel yönetimlerin ticari bankalardan kullandığı krediler de zaman içerisinde artış göstermiş ve 2013 yılı itibarıyla İller Bankası'ndan kullandırılan kredileri 
aşmıştır. Banka kredi faizleri \%7 ila \%15 arasında değişmekte olup, kullandırılan kredilerin ortalama maliyetine ilişkin kamuya açık kaynaklarda bir veriye ulaşılamamıştır. Hazine'nin TL cinsi sabit faizli iç borçlanmalarının ise 2012-2015 yılları arasında sırasıyla \%8,8, \% 7,6, $\% 9,7$ ve \%9 faiz oranıyla gerçekleştirildiği, 2015 yılında TL cinsi kuponlu TÜFE'ye endeksli DİBS ihraçlarının maliyetinin ise reel olarak \%1 ile \%1,3 arasında değiştiği görülmektedir ${ }^{11}$. Dolayısıyla Banka piyasa koşul ve oranları ile uyumlu olmayan bir kredi politikası sürdürmektedir (Şimşek, 2007: 54).

\section{Sonuç ve Öneriler}

Yukarıdaki bölümlerde yer alan veriler ve açıklamalardan çıkan sonuçlar tarafımızca aşağıda maddeler halindesıralanmıştır:

- Yerel yönetim bankacılığı yerel yönetimlerin finansmanında tüm dünyada kabul gören bir uygulamadir.

- Yerel yönetim bankaları finansman kaynaklarını sermaye piyasalarından uzun vadeli borçlanma araçları ihracı yoluyla sağlamaktadırlar.

- Yerel yönetim bankaları içinde bulundukları ülke merkezi yönetiminin borçlanma maliyetinin 15 ila 100 baz puan üzerinde borçlanma gerçekleştirebilmektedirler.

- Yerel yönetim bankaları düşük genel yönetim ve operasyon giderleri ile çalışmaktadırlar.

- $\quad$ İller Bankası kendisine temel misyon olarak yatırım ve danışmanlık işlevini almıştır. Gerek mali yapı ve operasyonları gerek personel yapısı Banka'nın kredi sağlama işlevini önceliklendirmediğini göstermektedir.

- $\quad$ İller Bankası özellikle altyapı ve üst yapı yatırımları için yerel yönetimlere uygun oranlarda kredi vermektedir. Ancak bu kredilerin vadesi 10 yilın altındadir.

- Kredilerin oranları düşük olmakla birlikte, Hazine'nin borçlanma maliyetinin $\% 9$ olduğu bir dönemde, tutarı ve toplam krediler içindeki oranı bilinmese dahi, altyapı yatırımları için $\% 7$ ile kredi vermesi rasyonel olarak açıklanamayacak bir durumdur.

- Banka kredilerin tamamına yakınınıözkaynaklarla finanse edilmektedir. Buna bağlı olarak daha önce yerel yönetimlerin toplam kredilerinin yaklaşık

11 Söz konusu veriler Hazine Müsteşarlı̆̆ı' nın kamu borç yönetim raporlarından temin edilmiştir. $<$ https://hazine.gov.tr/tr-TR/Rapor-Sunum-Sayfasi?mid=614\&cid=22\&nm=40\#.>, 01.09.2015. 
\%60’ını karşılayan Banka'nın, yerel yönetimlerin kredi hacmindeki ağırlığı \%42'lere kadar düşmüştür.

- Banka'nın faaliyet yapısı uluslararası anlamda uygulanmakta olan yerel yönetim bankacılığ

- Banka'nın ödenmiş sermayesinin ana kaynağı merkezi yönetim tarafından yerel yönetimlere aktarılan transferlerden alınan paylardır. Dolayısıyla Banka-yerel yönetim ilişkisinde yerel yönetimler aslında hakları olan tutarları teknik hizmet ve uzmanlaşma gibi dışsallıklar karşılığında kredi olarak kullanmaktadırlar.

- $\quad$ Yerelleşme ve kentleşme düzeyindeki artışa bağlı olarak artması beklenecek yerel yönetim borçlanma ihtiyacına Banka'nın mevcut finansman ve kredi politikası ile karşılık vermesi mümkün görülmemektedir. Yerel yönetimlerin ticari bankalardan kullandığı kredilerde tutar ve oran olarak artışlar beklenmesi kaçınılmazdır.

- Banka’nın yurtdışı uygulamalarda olduğu üzere ulusal ve uluslararası sermaye piyasalarından yabancı kaynak sağlaması ve uygun koşullarda yerel yönetimleri finanse etmesi yerel yönetimlerin finansman maliyetlerinde orta ve uzun vadede bir azalma sağlayabilecektir.

$\mathrm{Bu}$ tespitler çerçevesinde; Banka'nın yerel yönetim bankacılığı uygulamaları çerçevesinde sermaye piyasalarından fon temin ederek yerel yönetimlere kredi kullandırmasına yönelik olarak önerdiğimiz 3 yöntem aşağıda yer almaktadır:

- $\quad$ Banka kredibilitesi ortaya konularak ulusal ve uluslararası piyasalardan genel yükümlülük tahvilleri ihraç edilerek fon temin edilmesi ve kredi olarak yerel yönetimlere kullandırılması veya Banka'nın mevcut bilanço yapısında yer alan alacaklar değerlendirilerek varlık teminatlı veya varlığa dayalı menkul kıymet ihracı gerçekleştirilmesi,

- Yerel yönetimlerin borçlanma ihtiyaçlarının ve borçlanma kapasitesinin her takvim yılı için belirlenmesi, bu çerçevede yerel yönetimler tarafından ihraç edilecek borçlanma araçlarının satın alınarak bir havuz oluşturulması ve bu araçlar dayanak gösterilmek suretiyle borçlanma aracı ihracı gerçekleştirilmesi,

- Banka'nın özellikle büyükşehir belediyelerinin ulusal ve uluslararası sermaye piyasalarından fon temin etmesine aracılık işlevini üstlenerek, gerekirse birden fazla büyükşehir belediyesini bir araya getirerek veya borçlanma araçlarında ilk yüklenici olarak faaliyette bulunulması ve ihraçların gerçekleştirmesi. 


\section{Şekil: 3 \\ İller Bankası Genel Yükümlülük Tahvili İhraç Modeli}

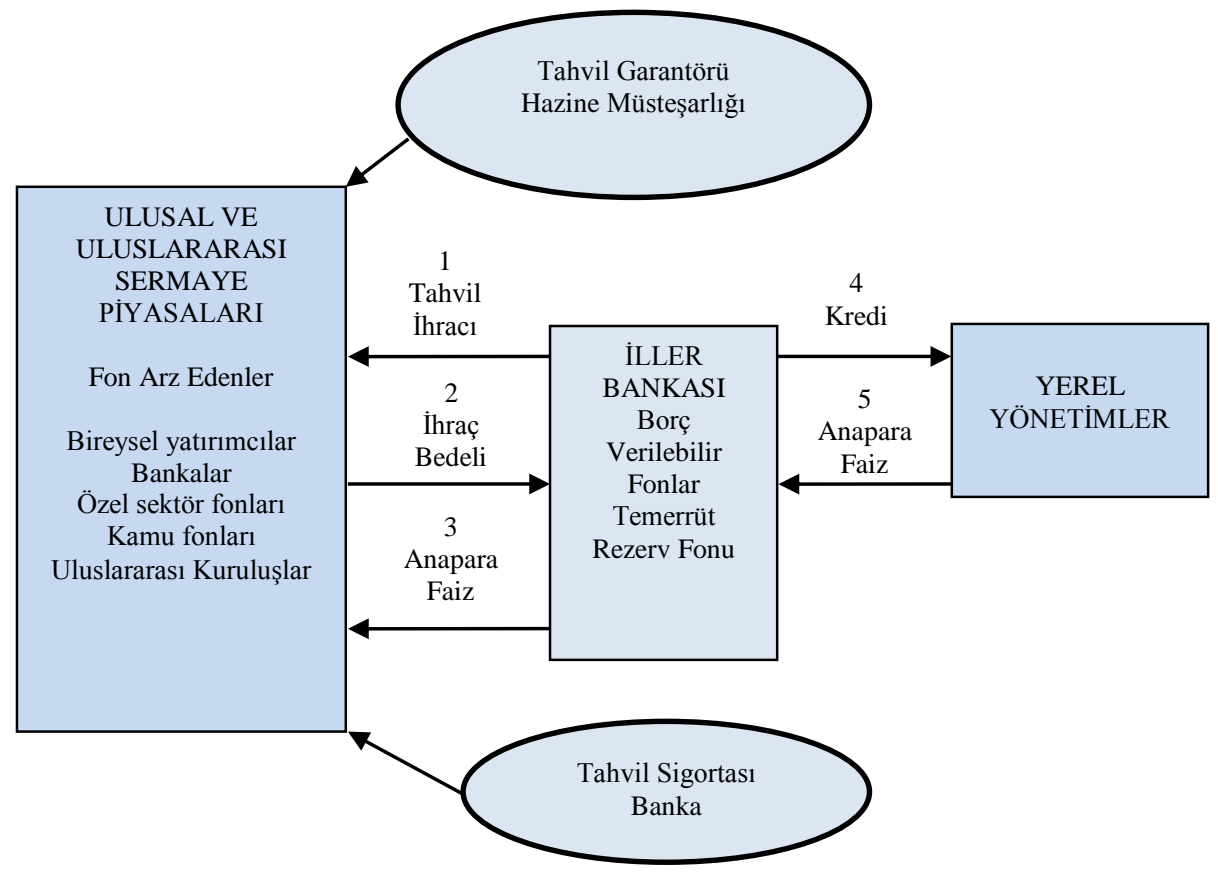

$\mathrm{Bu}$ yöntemlerden ilk ikisi Banka'nın mali yapısı ile direk ilgili olup, Banka'yı yükümlülük altında bırakacaktır. Büyükşehir belediyelerin borçlanma aracı ihracına aracılık ettiği üçüncü durumda, yüklenim de yapmadığı varsayılırsa, Banka sadece aracılık işlevini yerine getirecektir. Ancak ilk uygulamalarda Banka'nın mali yükümlülük altına girmesinin piyasada talep oluşması için gerekli olduğu düşünülmektedir.

İlk iki yöntemde İller Bankası tarafından yapılacak tahvil ihraçlarının anapara ve faiz ödemelerinde Hazine garantisi verilmesi de tahvil ihraç maliyetini düşürecek önemli bir uygulama olacaktır.

İkinci yöntemin uygulanması durumunda (Şekil 4) herhangi bir yerel yönetimin yükümlülüklerini yerine getirememesi durumuna karşıllk olmak üzere tahvil ihraç gelirlerinin belirli bir oranının garanti fonu olarak ayrılması, tüm yerel yönetimlerin borçlanmaların tamamından nüfusları veya gelirleri gibi oranlar belirlenmek suretiyle sorumlu olması talep oluşturulması açısından önemli görülmektedir.

İkinci ve üçüncü yöntemin uygulamasında yerel yönetimlerin borç servis oranları, borçlanma kapasiteleri gibi birden fazlakriter belirlenerek, bu kriterler çerçevesinde borçlanma üst limitleri dâhilinde borçlanmaya izin verilmesi önem arz etmektedir. 
Şekil: 4

İller Bankası Yerel Yönetim Tahvillerine Dayalı Borçlanma Aracı İhracı

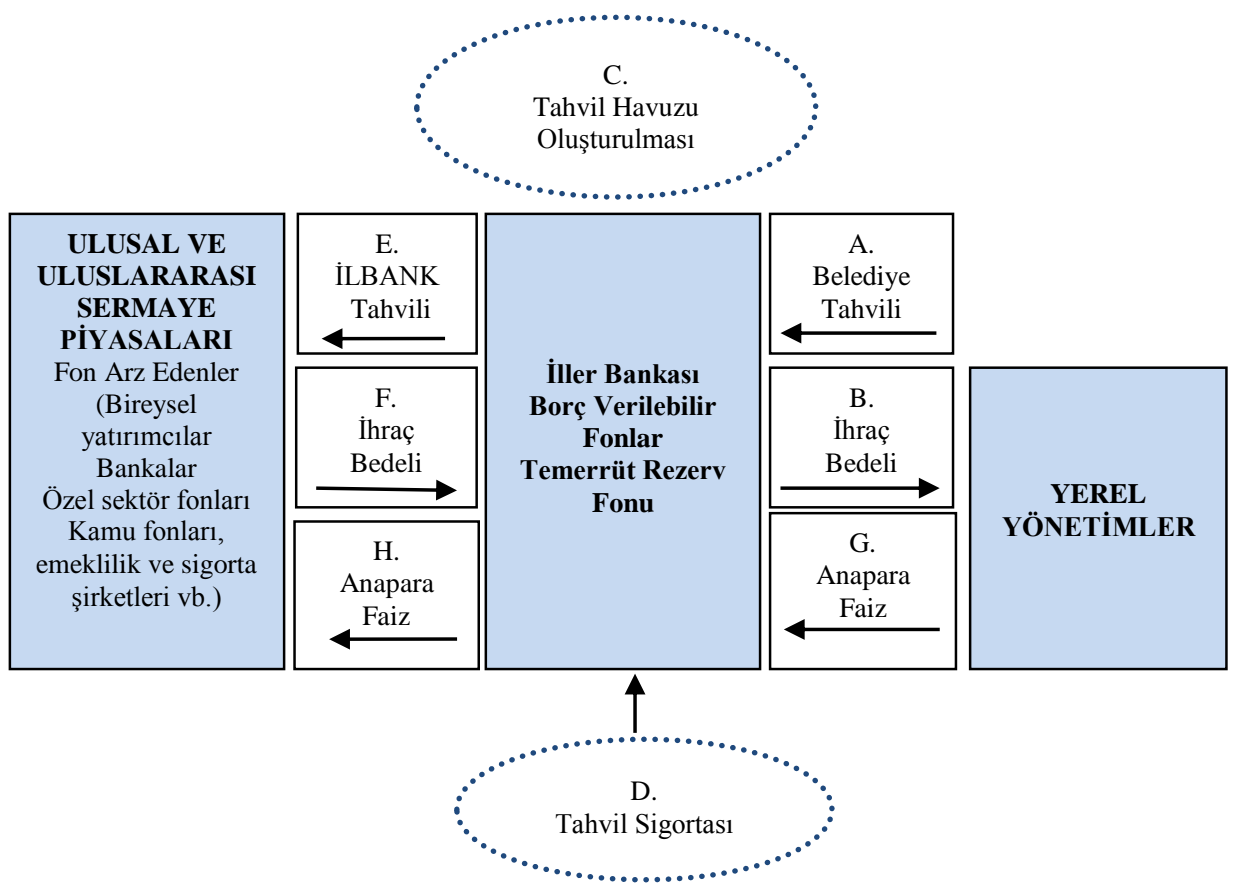

İller Bankası'nın aracılık görevini üstlendiği üçüncü yöntemde talep oluşturulmasını teminen aşağıdaki hususlara ilişkin çalışmalar yapılması gerektiği düşünülmektedir:

- Yerel yönetimlerin mali yapılarının ve finansal tablolarının şeffaflığının sağlanması, finansal tablolarının bağımsız denetim uygulamalarının bu kurumlarda başlatılması,

- Belediyeler tarafindan Banka'ya ve ilgili kamu otoriteleri olan Sermaye Piyasası Kurulu ve Bankacılık Denetleme ve Düzenleme Kurumu'na düzenli raporlamalar yapılmasının temini,

- Anapara ve faiz ödemelerinin merkezi hükümet transferleri veya belirli gelirler tahsis edilmek suretiyle garanti altına alınması şartıyla tahvil ihracına izin verilmesi.

Her 3 yöntemde de ihraç edilen tahvillerde elde edilen faiz gelirlerinin kamu tahvil gelirleri ile aynı statüde sayılması, hatta ABD uygulamasında olduğu üzere daha iyi koşullarda vergilendirilmesi bu finansal araçların ilk dönem ihraçlarını teşvik için önemli 
olacaktır. Ayrıca bu tahvillerin ikincil piyasasının oluşturulmasına yönelik Borsa İstanbul bünyesinde çalışmalar yapılması da üzerinde çalışılmayı gerektiren diğer bir husustur.

Diğger taraftan ilk iki modelin uygulanmasında kaynakta kesme (interception) olarak ifade edebileceğimiz yöntemin uygulanması tahvilin pazarlanması ve talep oluşturulmasında önem arz edecektir. Bilindiği üzere 5779 sayılı İl Özel İdarelerine ve Belediyelere Genel Bütçe Vergi Gelirlerinden Pay Verilmesi Hakkında Kanunun 7'nci maddesi uyarınca yerel yönetimlerin İller Bankasına olan borçlarına karşılık, genel bütçe vergi gelirleri tahsilatı toplamı üzerinden ayrılacak belirli bir tutardan kesinti yapılması mümkündür. Söz konusu kesintilerin nasıl yapılacağı ve kesinti oranları 2010/238 sayıl1 Bakanlar Kurulu Kararı'yla düzenlenmiş olmakla birlikte, her yıl çıkarılan ek Bakanlar Kurulu Kararları ile kesinti oranları "yüzde sıfır” düzeyine indirilerek kesinti yapılmaması yoluna gidilmiştir. Önerdiğimiz modellerin uygulanmasında bu mevzuatın işler hale getirilmesi tahvilin kredi değerliliğini artıracaktır.

Sonuç olarak yerel yönetim bankacılığı uygulaması yerel yönetimlerin finansmanında ticari bankalar lehine gelişmekte olan süreçte, maliyet avantajı ve kamu tasarrufu oluşturulması açısından önem arz etmektedir. İller Banka'sının mevcut faaliyet yapısı ile bunu gerçekleştirmesi mümkün görülmemektedir. İller Banka’sının bu anlamda yeniden yapılandırılması, başka bir kamu yatırım bankasının bu misyonla faaliyetlerine devam etmesi veya İller Bankası'nın yatırım ve finans bölümünün bu bankaya aktarılması veya yerel yönetimler tarafındanbu amaçla başka bir yatırım bankası kurulması uygulanabilir seçenekler olarak değerlendirilmektedir.

\section{Kaynaklar}

Babacan, A. (2014), "Yatırımcılar için Altyapı Finansman Araçlarının Geliştirilmesi Konferansı”, 19 Haziran 2014 tarihli Konferans Açılış Konuşma Metni, <http://www.hazine.gov.tr/default.aspx?nsw=NeC8XTWCQU/Qg42qeuYlIA==H7deC+LxBI8=\&cb=cb_bakan\&nm=94->, 04.07.2014.

Berk, A. (2003), “İller Bankası ve Yerel Yönetimler”, Sayıştay Dergisi, 48, Ocak-Mart, 75-92.

Brady, A. \& L. Andersson \& F. Breedon (2014), "The UK Municipal Bond Agency - Report to the Executive Board of the Local Government Association", <http://www.local.gov.uk/finance/-/journal_content/56/10180/3684139/ARTICLE>, 09.07.2015.

CLAIR - Council of Local Authorities for International Relations (2010), LocalGovernment in Japan, <http://www.clair.or.jp/e/pub/surveys.html>, 04.04.2016.

Cole, C.W. \& J.A. Millar (1982), “The Impact of Municipal Bond Banking on Municipal Interest Costs", Financial Management, 11(1), Spring, 70-76.

İller Bankası A.Ş. (2013), 2012 Yllı Faaliyet Raporu, <www.ilbank.gov.tr>, 29.09.2015.

İller Bankası A.Ş. (2014), 2013 Yll Faaliyet Raporu, <www.ilbank.gov.tr>, 29.09.2015.

İller Bankası A.Ş. (2015), 2014 Yllı Faaliyet Raporu, <www.ilbank.gov.tr〉, 29.09.2015. 
Gümüş, M. \& A.B. Yereli (2016), "Yerel Yönetimlerin Finansmanında Yerel Yönetim Bankacıllğ Uygulaması, İller Bankası Örneği ve Türkiye İçin Öneriler”, Sosyoekonomi, Vol. 24(28), 209-234.

JFM (2015), Annual Reports, <http://www.jfm.go.jp/en/investors/financial.html\#annual>, 25.08.2015.

JLGB (2014), "Japan Finance Organization for Municipalities", JLGB Avrupa Organizasyonu Sипити, Ekim, <http://www.chihousai.or.jp/english/07/investor12.html>, 21.08.2014.

Katzman, M.T. (1980), "Municipal Bond Banking: The Diffusion of a Public-Finance Innovation”, National Tax Journal, Vol: XXXIII, 149-160.

Kestane, D. (1996), “İller Bankası ve Yerel Yönetimlerle İlişkiler”, Devlet Bütçe Uzmanlı̆̆ Araştırma Raporu.

Kidwell, D.S. \& R.J. Rogowski (1983), "Bond Banks: A State Assistance Program That Helps Reduce New Issue Borrowing Costs", Public Administration Review, March-April, 108113.

MUNIFIN of Finland, KOMMUNEKREDIT of Denmarkand KOMMUNINVEST of Sweden (2012), The Nordic Model - Local government, global competitiveness in Denmark, Finland and, Sweden, <https://www.munifin.fi/invest-munifin/nordic-model>, 04.08.2015.

MUNIFIN of Finland (2015), Annual Reports, <https://www.munifin.fi/about-us/key-figures-0>, 04.08.2015.

MUNIFIN of Finland (2015-1), MUNIFIN Presentation May 2015, <https://www.munifin.fi/investmunifin/investor-facts>, 04.08.2015.

McKinsey Global Institute (2013), Infrastructure Productivity: How to save \$1 trillion a year, <http://www.mckinsey.com/ /media/McKinsey/Industries/Infrastructure/Our\%20Insight s/Infrastructure\%20productivity/MGI\%20Infrastructure_Full\%20report_Jan\%202013.as $\mathrm{hx}>, 25.09 .2015$.

Rhee, S.G. \& G.R. Stone (2003), "The Asian Bond Bank: A Good Idea to Explore for Credit Enhancements", Background Reference Material for the Second Annual Conference of the PECC Finance Forum on "Issue and Challenges for Regional Financial Cooperation in the Asia-Pacific",

<http://www2.hawaii.edu/ fima/Working_Papers/2003_papers/WP03-03.pdf>, 11.07.2015.

Robbins, M.D. \& D. Kim (2003), "Do State Banks Have Cost Advantages for Municipal Bond Issuance?", Public Budgetting \& Finance, Fall, 1-24.

Şimşek, A.A. (2007), "Yerel Yönetim Bankacılığı İller Banaksının Değişim Süreci Üzerine Bir İnceleme", Gazi Üniversitesi Fen Bilimleri Enstitüsü, Yüksek Lisans Tezi.

USAID (2005), "Municipal Finance: Increasing Local Government Resources to Fund MultiSectoral Facilities", Background Paper, Washington D.C.

<https://collaboration.worldbank.org/docs/DOC-7510>, 04.04.2015.

Vermont Municipal Bond Bank (2014), 2013 Annual Report, <http://www.vmbb.org/about/annualreports-audits/>, 24.09.2015.

Vogt, M.G. (1984), "Municipal Bond Banks and Their Effects on the Finances of Local Governments", Quarterly Journal of Business and Economics, 23(1), 38-50. 